International Business and Global Economy 2017, no. 36, pp. 183-205

Biznes międzynarodowy w gospodarce globalnej 2017, nr 36, s. 183-205

Edited by the Institute of International Business, University of Gdańsk

ISSN 2300-6102

e-ISSN 2353-9496

DOI 10.4467/23539496IB.17.013.7461

Piotr Konwicki

University of West London, Claude Littner Business School

\title{
Islamic finance: Challenges in 2017 and further ahead
}

The article presents the growth story of Islamic financial institutions in the $21^{\text {st }}$ century, observed mostly through the growth in the Islamic assets worldwide. Based on the structural analysis of this Sharia-based system (Sharia defined as a system of legal and ethical norms, based on Qur'an and Sunnah, further developed into figh), the article offers a multi-faceted analysis of the current state of Islamic finance. The purpose of the article is to critically analyse the current state of Islamic financial institutions and to identify the key risk areas, constituting important development barriers for the sector. The key identified barriers are: concentration of assets within banking sector, heavy geographical and sectoral exposure, small average size of Islamic financial institutions, lack of clear governing standards, complicated product structures, and lack of skilled personnel. The article also presents secular factors supporting further developments of Islamic finance, mainly rapid growth of Muslim population worldwide and potential ethical aspect of the sector's risksharing model, leading to its ability to reach out beyond Muslim communities. The article predominantly applies a deductive method, based on a secondary data analysis, using the latest available market data and policy papers from institutions like the World Bank Group. Sections of the article draw on the author's current research on linkages between the structure of the UKbased Islamic banks and their operating cost base.

Keywords: general economics, international finance, globalisation, Islamic economic and financial system

JEL classification: A13, F3, F4, P4

\section{Islamski sektor finansowy - wyzwania w roku 2017 i w latach następnych}

Artykuł przedstawia historię rozwoju islamskich instytucji finansowych od początku XXI wieku, głównie w ujęciu wzrostu ich aktywów. Na podstawie analizy strukturalnej islamskiego systemu ekonomicznego, opartego na szariacie (całościowy system norm prawnych oraz etycznych bazujących na Koranie i sunnie, wiążący społeczność muzułmańską), artykuł przedstawia jego obecną strukturę w wielopłaszczyznowym ujęciu. Celem artykułu jest krytyczna analiza obecnego stanu islamskiego sektora finansowego i wskazanie kluczowych obszarów ryzyka, stanowiących istotne bariery dla dalszego rozwoju. Głównymi barierami są nieproporcjonalnie wysoka koncentracja aktywów w sektorze bankowym przy równoczesnej małej roli pozostałych obszarów, takich jak ubezpieczenia czy zarządzanie aktywami, znacząca geograficzna i sektorowa koncentracja aktywów, niewielki przeciętny rozmiar islamskich instytucji finansowych, brak jasnych standardów korporacyjnych oraz wytycznych odnośnie zastosowań szariatu w praktyce gospodarczej, skomplikowana struktura oferowanych produktów oraz brak wykwalifikowanych 
kadr. Artykuł przedstawia również sekularne czynniki sprzyjające rozwojowi finansów islamskich, gównie szybki wzrost ilości wyznawców Islamu na świecie oraz etyczną atrakcyjność modelu tego sektora, opartego na podziale ryzyka pomiędzy partnerami, co potencjalnie otwiera możliwość ekspansji poza światem muzułmańskim. W artykule zastosowano głównie analizę opisową, opartą na literaturze naukowej, raportach rynkowych oraz danych statystycznych. Część artykułu wykorzystuje obecnie trwające badania autora dotyczące związku pomiędzy strukturą islamskich banków działających w Wielkiej Brytanii a poziomem ich kosztów operacyjnych.

Słowa kluczowe: ekonomia, finanse międzynarodowe, globalizacja, islamski system ekonomiczny i finansowy

Klasyfikacja JEL: A13, F3, F4, P4

\section{Introduction}

This article presents the current status of Islamic finance against the background of its slowing growth. The author aims to (1) analyse selected key features of Islamic financial institutions that may create barriers for further development of the sector and (2) present secular factors supporting the sector's expansion, also outside the Muslim world.

\section{Definition of Islamic finance}

Islamic finance (IF) is described as any financial activity that is undertaken in accordance with Islamic (Sharia) law principles [Jessop, 2009]. The Sharia law is not a standard body of law and its primary sources are:

- the Noble Qur'an (divine word of God),

- the Sunnah ${ }^{1}$,

- the Ijtihad ${ }^{2}$.

Since the Noble Qur'an does not provide a definitive answer for many practical finance questions, figh (Islamic jurisprudence) was developed in order to:

- elaborate the principles of Sharia found in the Noble Qur'an,

- apply them to all manner of real-life situations,

- give Muslims guidance on how to act.

The distinction between Sharia and figh is important. Sharia is the Islamic law, handed down by God and therefore sacred and inviolate. Figh, by contrast, is the science of interpreting Sharia, codifying it, and applying it to all aspects of life. It is done by humans, and therefore not sacred.

1 The Arabic word sunnah lexically means 'road' or 'practice'. In the language of the Prophet and the Companions it denotes the whole of lawful practices followed in the Religion, particularly the pristine path of Prophets, whether pertaining to belief, religious and social practice, or ethics.

2 Ijtihad is the endeavour of a Muslim scholar to derive a rule of divine law from the Qur' an without relying on the views of other scholars. 
The World Bank report on Islamic finance [WB, 2016] refers to the so-called four pillars of Islamic economy:

- existence of an institutional framework and public policy in line with the objectives of Islam,

- prudent governance and accountable leadership,

- promotion of the economy based on risk-sharing and entrepreneurship,

- financial and social inclusion for the entire society.

Figure 1 visualises the above concept and presents the relationships between the pillars.

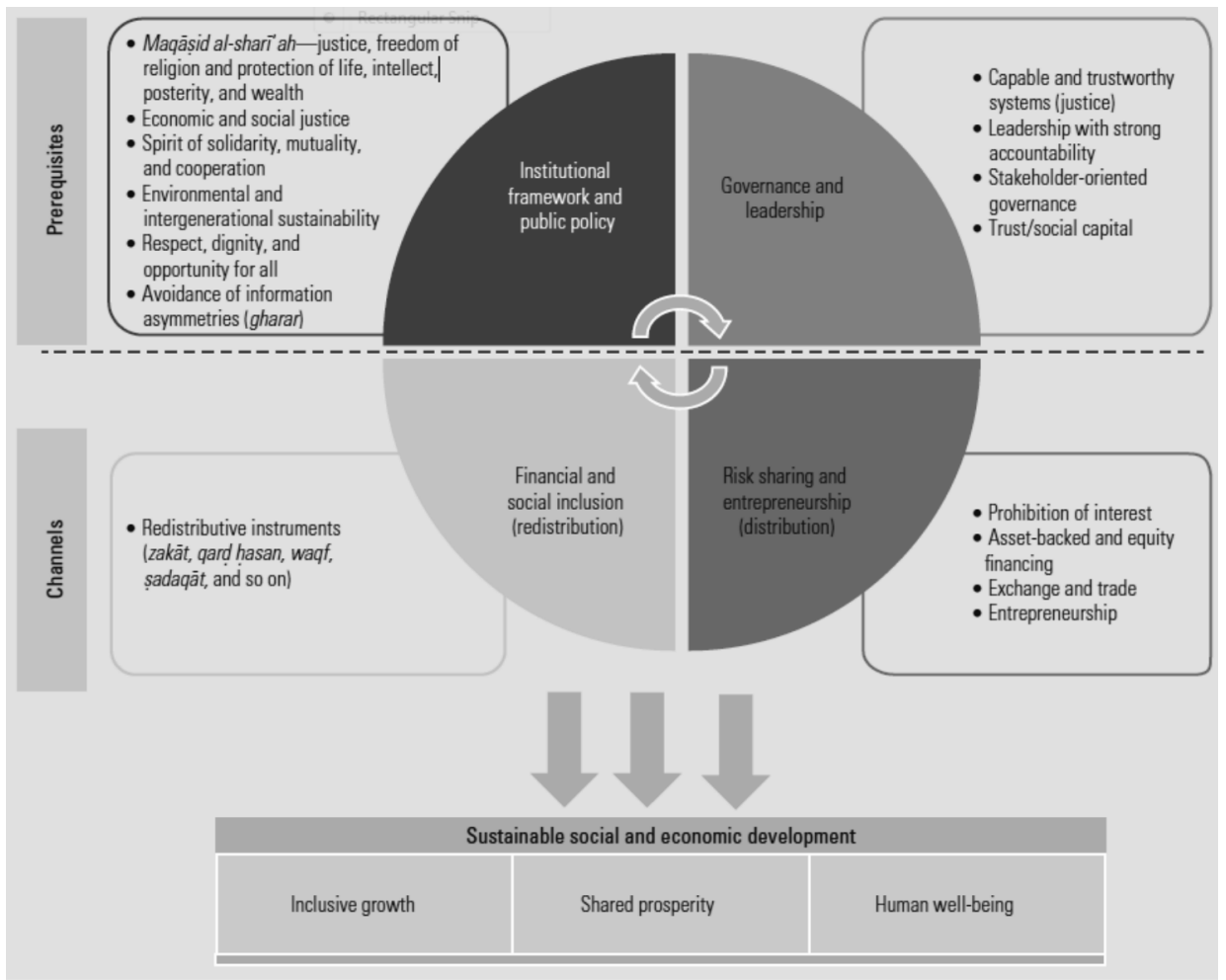

Figure 1. Four pillars of the ideal Islamic economy

Source: [WB, 2016].

The ideal structure of an Islamic economy and finance is based on strong belief in the concepts of property rights, contracts, trust, and functioning markets ${ }^{3}$.

3 For an extended discussion and presentation of property rights, contracts, trusts, obligation not to harm, and a principle of free flow of information (so-called five pillars of market institutional infrastructure) please refer to other literature sources, in particular: [Iqbal, Mirakhor, 2011]. 
El Hawary, Grais, and Iqbal [2004] further define IF as a financial system that obeys the following four principles:

- risk-sharing between company and individual: the settings of financial transactions must represent a balanced risk/return distribution among the contributors,

- materiality: commercial transactions must involve real economic transactions; a practicing Muslim cannot make money from money as it has no intrinsic value - hence, 'usury' (payment and receipt of interest) is forbidden,

- no exploitation: neither party of the commercial transaction may be exploited,

- no financing of sinful activities: transactions cannot be used to offer products or services which are banned by the Qur'an, such as alcohol, gambling, or pornography 4 .

Bank of England [2017] defines IF as an activity deemed to be consistent with the Islamic law, Sharia. Among these principles are:

- the Aristotelian notion that money has no intrinsic value and should serve only as a medium of exchange,

- emphasis on real economy activity and consequent risk- and reward-sharing,

- prohibition on involvement in what are considered to be socially detrimental activities,

- prohibition on riba (interest) ${ }^{5}$.

This paper will apply the above understanding of IF.

\section{Recent growth of the Islamic finance and its potential}

Islamic finance is one the fastest growing areas of finance in $21^{\text {st }}$ century, with assets ascending from US\$ 600bn in 2007 to over US\$1.3tn in 2012. Figure 2 shows the growth of the Islamic finance.

Despite their meteoritic growth in the last decade, the combined assets of Islamic institutions are still low in comparison with those of traditional Western financial institutions - for example on December 31, 2014, JP Morgan Chase \& Co. had US\$ 2.57tn of assets [JP Morgan Chase].

The Islamic finance industry continues to grow - the latest CityUK report, published in November 2015, estimates that the global market for Islamic financial services, as measured by Sharia-compliant assets, increased by $12 \%$ in 2014 to a record level of US\$ $2 \mathrm{tn}$. Initial data for 2015, however, show that Islamic finance recorded its first fall in decades - total banking assets fell by $8.48 \%$ - and even if

4 This definition is also used by the World Bank in its report on Islamic finance [WB, 2016, p. 57].

5 There is no clear agreement what the Arabic word riba actually means, as it may mean either interest or usury; in any case, trading in debt at other than par value is prohibited; this also entails avoiding equity investments in highly leveraged firms. 
this can be attributed to a one-off event $(1 / 3$ devaluation of local currency in Iran led to a dramatic decrease of banking assets measured in US\$), it is an important event in the industry, which can no longer rely on ever-increasing oil revenues flowing into Islamic institutions [The Banker, 2015]. Currently there are 1,143 Islamic finance institutions with total assets of US\$ 1.818tn [Dudley, 2016] ${ }^{6}$.

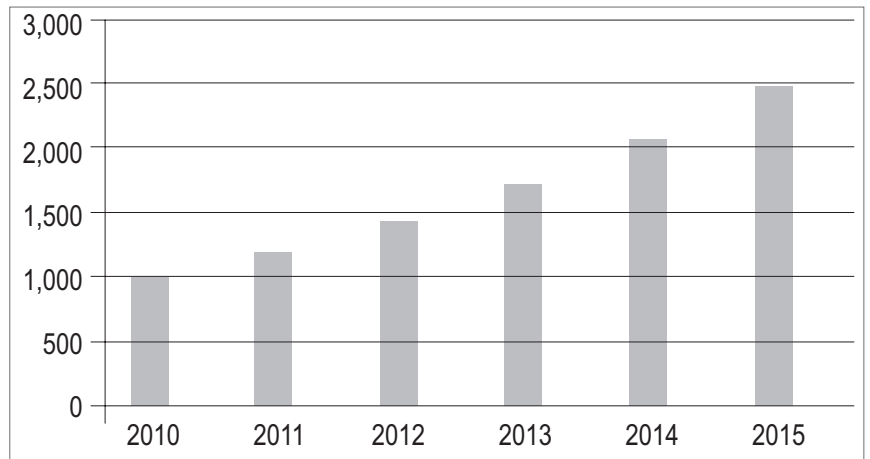

Figure 2. Islamic finance: Growth of assets (US\$ mn)

Source: [The Banker, 2015].

However, as with any fast-growing products (not only financial), initial high growth can partially be attributed to a low comparison base - it is easier to achieve a faster growth if the starting point is low. This general view is confirmed by Figure 3.

Although the growth of Islamic finance is slowing down, there is a considerable potential for its expansion. As of 2010, Islam was the second most popular religion in the world, with 1.6 billion adherents, or $23 \%$ of the global population [PEW, 2015], but Sharia-compliant assets make up only around 1\% of the world's financial assets. Less than a fifth of Muslims worldwide currently use Islamic financial products. There are also signs of Islamic finance reaching outside its traditional base of Muslim customers. There is an interesting example of Al Rayan Bank, the UK subsidiary of Qatari bank Masraf Al Rayan. Its turnover improved from a meagre GBP 3.67mn in 2011 to almost 30mn in 2015. Figure 4 shows the evolution of Al Rayan's financial performance. The main contributing factor is, according to Sultan Choudhury, chief executive of Al Rayan, that the majority of Al Rayan Bank's long-term depositors are non-Muslims [Dudley, 2016].

6 On a cautionary note, even the actual size of assets of Islamic finance is difficult to measure. The difficulties start with a definition of what constitutes Islamic assets or institutions (some databases even include Islamic multinational institutions, such as the Islamic Development Bank, in its calculations). In addition, due to the concentration of Islamic assets in a few countries, any valuation of Islamic assets does strongly depend on exchange rate between US\$ and a few key currencies (Saudi riyal, Malaysian ringgit, Iranian rial). 


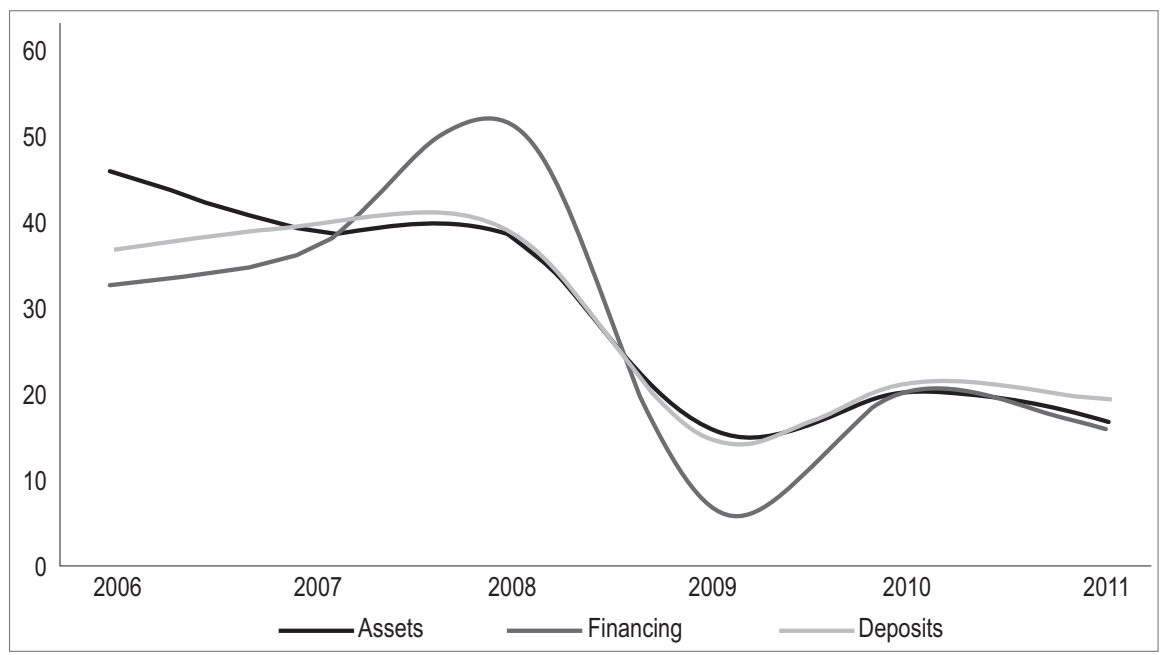

Figure 3. Average growth trend of Islamic banking globally (in \%) Source: [IFSB, 2013].

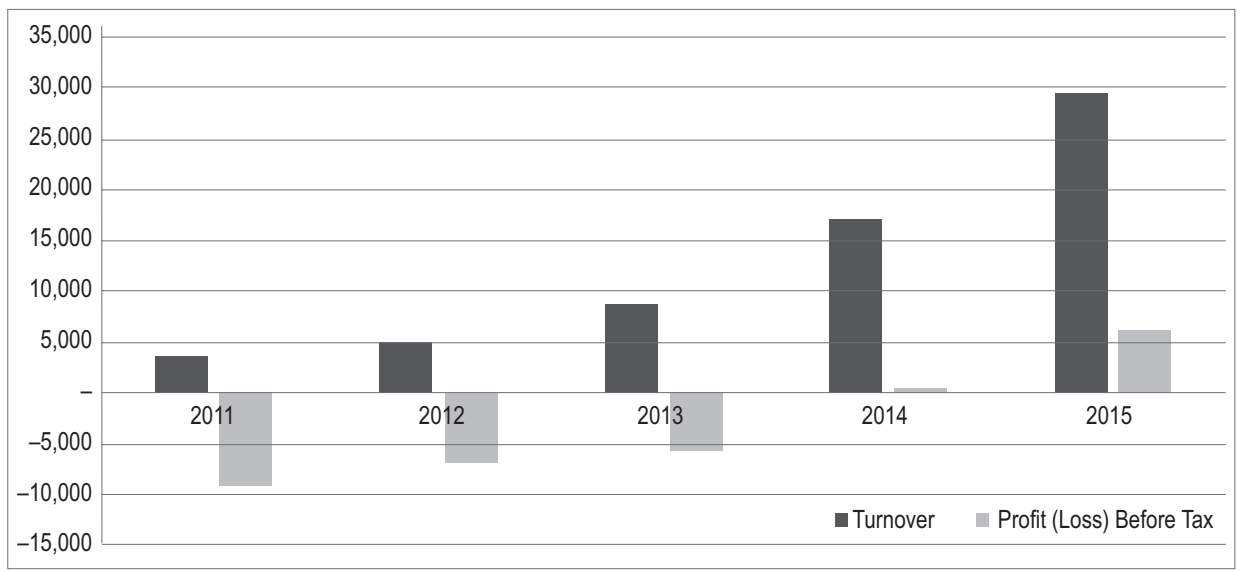

Figure 4. Al Rayan Bank, financial data (in GBP thousand)

Source: Own elaboration based on: [FAME].

United Kingdom is also the first non-Muslim country to issue a sovereign suk $\bar{u} k$ (type of Islamic bond, or, to be more precise, financial certificate generating a steady financial flow for its buyer) in June 2014 [Gov.UK, 2014], quickly followed by Luxembourg in October 2014 [Vizcaino, 2014]. Bank of England [2017] also started a discussion on creating a Sharia-compliant liquidity facilities available to Muslim banks worldwide, which further confirms the growing outreach of Islamic finance. 
Proponents of Islamic finance stress its communitarian vision, according to which Muslims with wealth should invest it productively to expand the welfare of the community. Islam makes it clear that this extension of community welfare applies to all people, not only Muslims. This has been noted by, i.a., L'Osservatore Romano, which wrote in 2009 that conventional banks should look at the rules of Islamic finance to restore confidence amongst their clients at a time of global economic crisis [Konwicki, 2015].

\section{The main challenges to Islamic finance}

Although Islamic finance continues to grow (even if at a slower rate than previously), there are many structural problems in the industry, which are likely to hinder its future growth and innovation.

\subsection{Structural problems: Dominance of banking assets}

The first of them is the structure of assets, with its heavy dominance on banking assets, as presented in Figure 5.

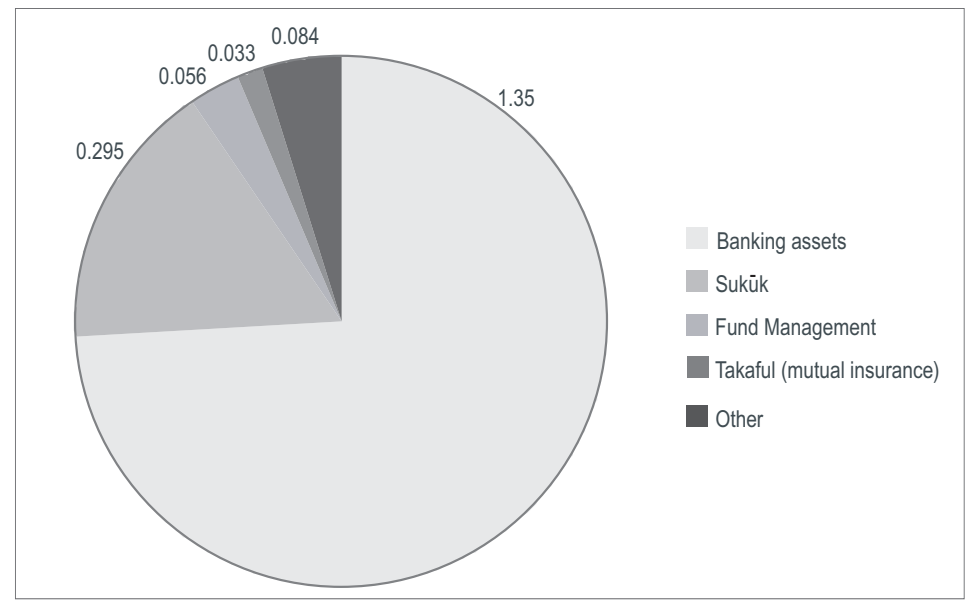

Figure 5. Most established forms of Islamic finance (US\$ tn)

Source: Own elaboration based on: [CityUK, 2015].

Moreover, the dominance of banking assets in the structure of Islamic finance is even more visible if analysed on a 'per country' basis, as in Figure 6.

The above structure contrast strongly with the global structure of financial assets presented in Figure 7. 


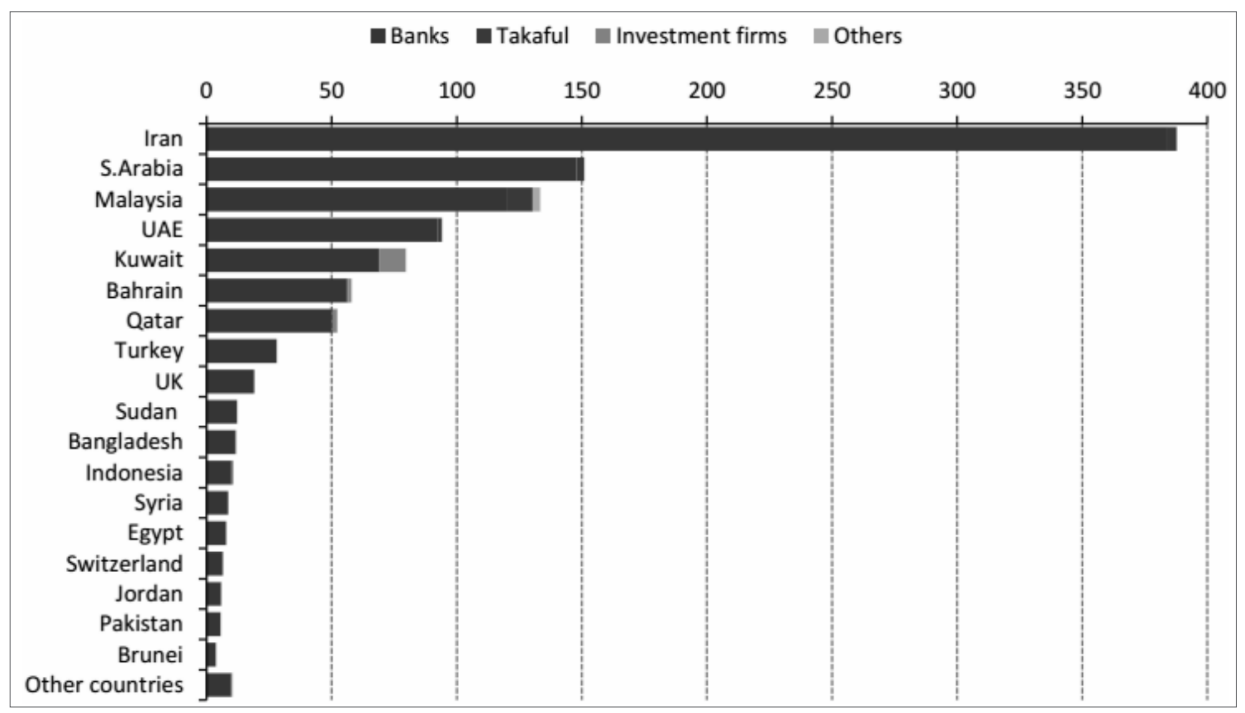

Figure 6. Structure of Islamic finance assets in selected countries Source: [The Economist, 2014].

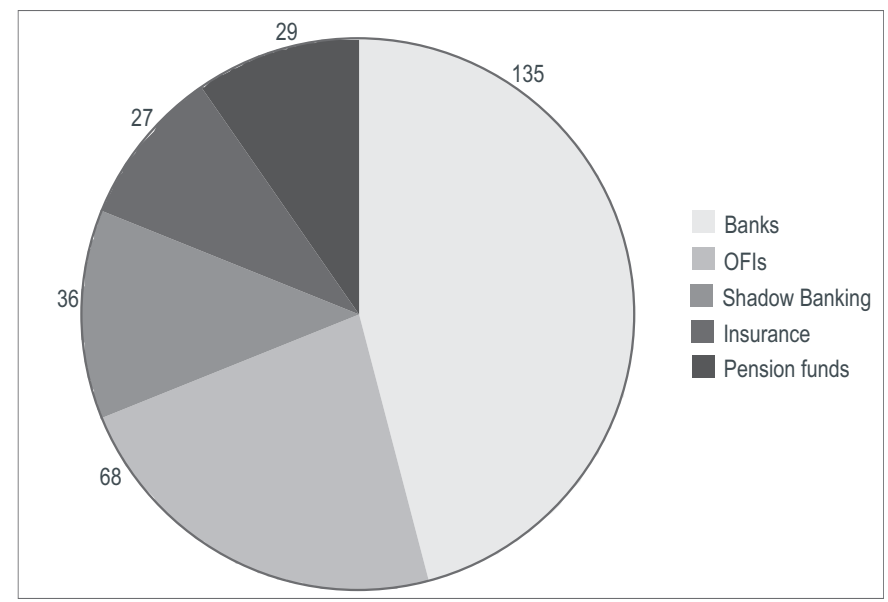

Figure 7. Global structure of financial assets (in US\$ tn)

Source: Own elaboration based on: [FSB, 2015].

\subsection{Structural problems: Size of financial institutions}

The difference in terms of size of the financial institutions, as compared with conventional financial institutions, is very visible. Figure 8 from AT Kearney's report shows this difference in the jurisdictions with well-developed Islamic finance. 


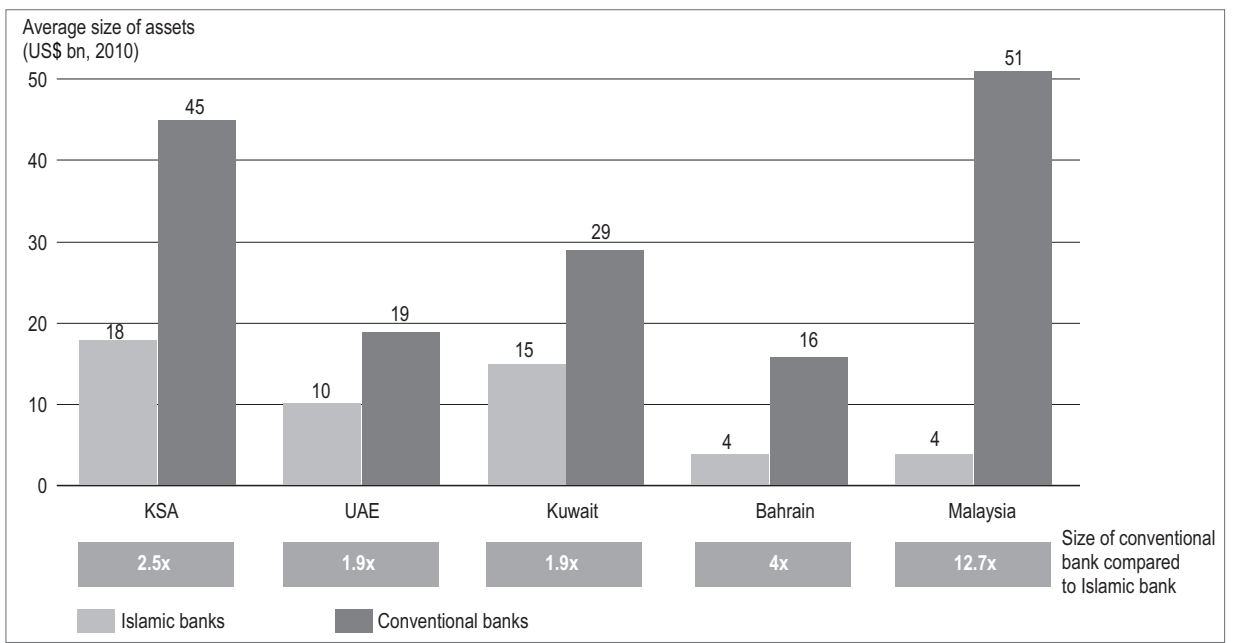

Figure 8. Size disadvantage of Islamic banks

Notes: Islamic assets of conventional banks are included within the size of 'conventional banks' as they are simply another product offering by the conventional bank.

Source: [AT Kearney, 2012].

The largest Islamic finance institution, Al Rajhi Bank Public Joint Stock Company, listed in Riyadh, KSA, with assets of US\$90.6bn at the end of 2016, occupies $258^{\text {th }}$ place on the list of banks ranked by their asset size [ORBIS] 7 . Inadequate size does have a negative impact on operating costs. Many bank processes in the Gulf Co-operation Council are still manual, involving a multitude of documents and layers upon layers of decision makers. This can be particularly cumbersome in Islamic banking as an asset transfer is often involved. The conventional industry practice refers to observations that redesigned processes can yield significant efficiency improvements, in some cases reducing resource requirements by $50 \%$.

\subsection{Structural problems: Sectoral exposure}

The smaller size of institutions does not support financial innovation and 'pushes' banks towards offering simplified products within limited business areas. This is confirmed by a narrow concentration of Islamic banks in selected sectors only. Typically, the largest sectors for Islamic banking loans are retail, real estate, and construction. Conventional banks tend to have greater exposure to a wider range of industries, such as the financial sector and manufacturing, as well as to trade finance. As a result, Islamic banks carry significantly larger industry risk in their portfolios compared with their conventional equivalents.

7 Special thanks to James Ralston from Bureau van Dijk, who made this search possible despite the University's lack of access to the ORBIS database. 


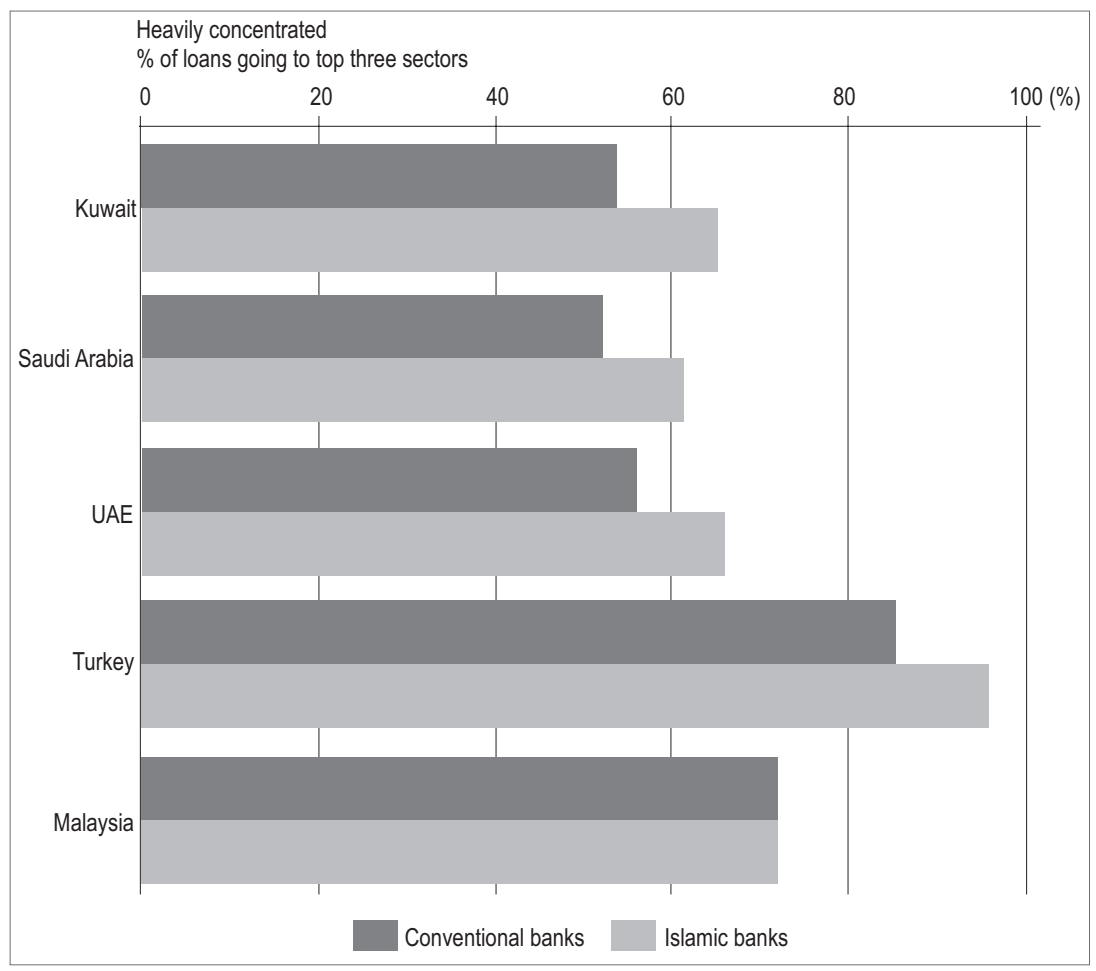

Figure 9. Sectoral concentration of Islamic banks

Source: [EY, 2015].

\subsection{Structural problems: Geographical concentration}

The poor risk profiles of many Islamic institutions, resulting from their small size and over-exposure to few sectors, are further weakened by heavy geographical concentration of their operations. Most of the Islamic institutions have only local presence, making them vulnerable to localised economic shocks. The problem is very visible also at the entire industry level. Around 93\% of Islamic banking assets are held in just nine markets: five of those are in the GCC, led by Saudi Arabia and including the UAE, Kuwait, Qatar, and Bahrain. The other four are Malaysia, Turkey, Indonesia, and Pakistan ${ }^{8}$. More than half of all Islamic finance assets are held by banks in just three countries: Malaysia, Saudi Arabia, and Iran [EY, 2015].

But even in these core markets, customers often prefer to bank with conventional lenders. EY reckons that only a third of banking assets in the Gulf Co-operation Council are Sharia-compliant.

8 These figures exclude Iran. 
Still a niche, even in most Muslim cultures

Islamic banks' share of banking market, \% of assets, 2014

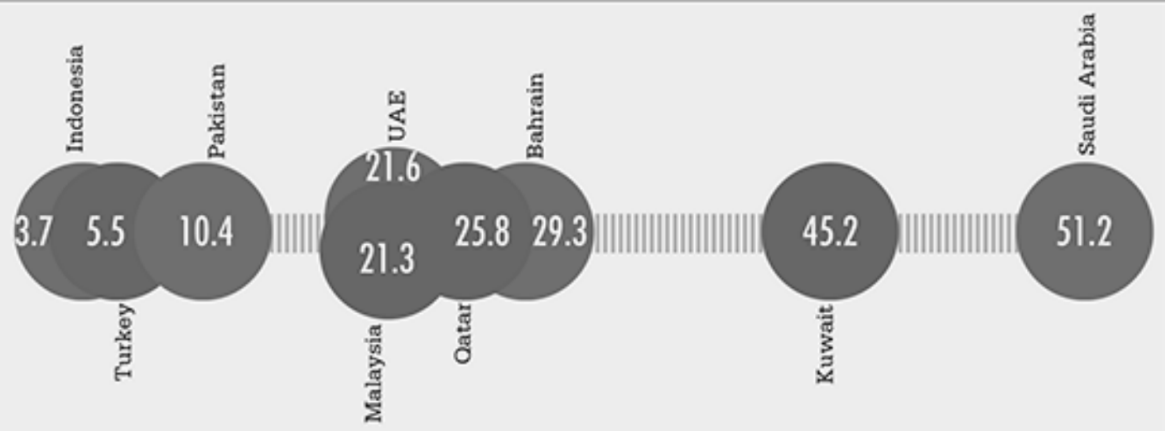

Figure 10. Geographical concentration of Islamic finance

Source: [EY, 2015].

\subsection{Lack of product standardisation}

Every Islamic finance entity must adhere to Sharia standards. This assurance is certified by Sharia Supervisory Board (SSB), which is a panel of Muslim scholars performing independent audits and supervision. SSB exists in addition to typical bank board governance structures, but its functions are mainly to certify (ex-ante) and to monitor (ex-post) all financial contracts, transactions, and further activities of a bank on behalf of shareholders, stakeholders, and clients to ensure that they are compliant with Sharia [Alman, 2012]. SSBs include some of the most prominent and respected scholars. Many of them are highly regarded, with their opinions having the potential to move markets. Nonetheless, since Sharia scholars are generally employed directly by financial institutions, their independence can be compromised, since bank managers use their influence to gain more acceptable opinions. This has been commonly referred to as 'fatwa shopping' or 'Sharia advisory a la carte'. Moreover, a decentralised approach to Sharia governance has led to further fragmentation in the industry, increasing transaction costs and overall efficiency of Islamic banks compared to conventional banks [Islamic Banker, 2017]. Furthermore, any Muslim scholar can issue an opinion ( fatwa) about any financial product which can lead to confusion among customers. Appendix 2 presents a detailed description of a case in which HSBC Ammanah introduced a house buying plan in the UK (the Islamic finance equivalent of a mortgage) with appropriate approval of its SSB, while a leading UK-based scholar challenged this approval and issued fatwa stating that this product was un-Islamic. Not surprising, the product was not successful in the UK and led to lack of trust among Muslim retail customers. 


\subsection{Complicated structuring of Islamic products}

Every Islamic financial product must meet the requirement and principles of Islam, most notably be asset-based and avoid excessive leverage, prohibited activities, uncertainty (gharar), speculation (maysir), and exploitation of ignorance.

Figure 11 presents the comparison of a conventional bond issuance with the development of sukūk (Islamic certificate used to achieve a similar effect).

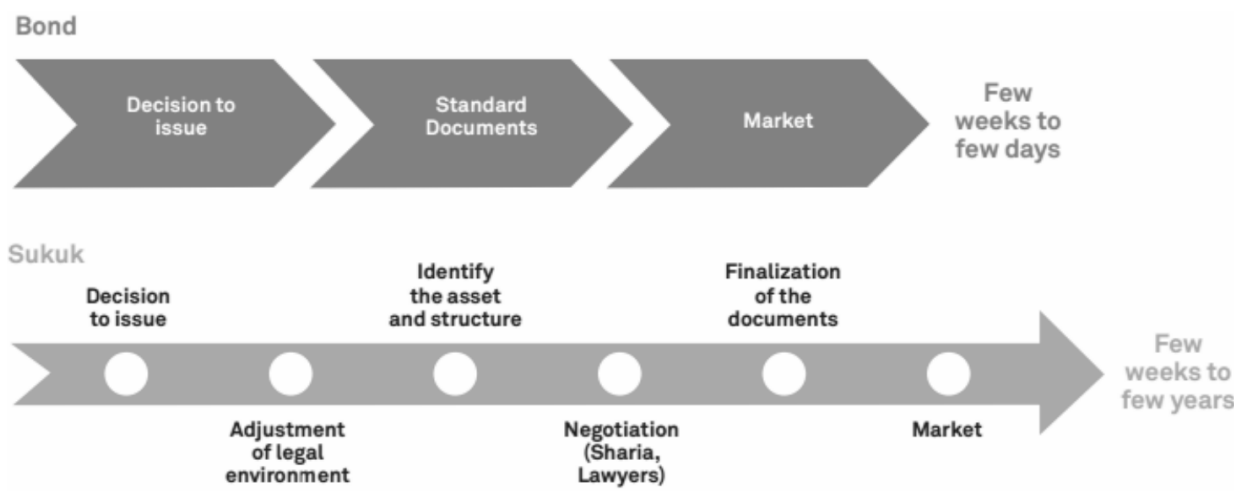

Figure 11. Conventional bond vs sukūk

Source: [Damak, 2017].

This structuring undoubtedly extends the time necessary to market a product. The author's interviews with the compliance departments of UK Shariacomplaint banks confirmed this view, difference depending on the level of product complication. In addition, adherence to Islamic procedures increases product development cost. While it is difficult to precisely assess it (the information is a highly protected commercial secret), in 2010 Malaysian Takaful (Islamic insurance) listed companies that had 50\% higher management cost ratio compared with traditional insurance firms [ORBIS]. Appendix 1 presents a detailed structure of UK sovereign sukük to illustrate the level of additional effort necessary to achieve a halal structure. In short, the UK government had to:

- identify relevant assets that belong to Her Majesty's Treasury,

- create special purpose vehicle (SPV) to which ownership of selected assets was transferred,

- make sure that the relevant government agency entered into a lease agreement with SPV,

- obtain required Sharia certificates,

- create legal documentation ascertaining reverse transfer of assets after expiration of sukūk. 


\subsection{Lack of skilled personnel}

According to a 2015 survey by the consultancy firm Middle East Global Advisors, $64 \%$ of the industry executives think that the availability of suitably qualified staff for the Islamic finance industry is limited. Further 18\% think that such people are very scarce, while only $18 \%$ think that there is adequate or abundant properly trained staff available [Dudley, 2016].

\section{Conclusions}

Islamic finance has achieved extraordinary growth since the beginning of $21^{\text {st }}$ century. The industry still remains, however, a niche player in the global finance sector. Its development has been hindered by the following structural factors:

- concentration of assets within the banking sector,

- heavy geographical and sectoral exposure,

- small average size of IF institutions,

- lack of clear governing standards,

- complicated product structures,

- lack of skilled personnel.

The above factors contribute to a higher cost base for each IF institution, although it is difficult to quantify their exact impact.

However, IF still offers a very significant development potential. Its risk and profit-sharing business model based on tangible assets is attractive, especially in the developing world. There is a huge untapped potential for the industry, resulting from the increasing world population of Muslims. Moreover, IF is showing signs of being able to break into the mainstream finance, as documented by its fast growth in selected European countries, such as the UK, Luxembourg, or Germany.

If Islamic finance is able to address the above-listed structural factors, it may become an important part of the world financial system.

\section{References}

Al-Haddad H., 2004, The ruling on the permissibility of financing properties using ijara Islamic mortgages, SunnahOnline.com, http://www.sunnahonline.com/library/contemporary/ 0038.htm [access: 15.10.2017].

Alman M., 2012, Shari'ah Supervisory Board composition effects on Islamic banks' risk-taking behavior, Bamberg University, Department of Management, Business Administration and Economics, http://www.efmaefm.org/0EFMAMEETINGS/EFMA\%20ANNUAL\% 20 MEETINGS/2013-Reading/papers/EFMA2013_0082_fullpaper.pdf [access: 15.10.2017].

AT Kearney, 2012, Perspectives of Islamic finance: Industry report, London. 
Bank of England, 2017, Shari'ah compliant liquidity facilities: Establishing a fund based deposit facility, consultation paper, http://www.bankofengland.co.uk/markets/Documents/ sclf_consultationpaper2017.pdf [access: 15.10.2017].

CityUK, 2015, The UK: Leading Western centre for Islamic finance, https://www.thecityuk.com/ assets/2015/Reports-PDF/The-UK-Leading-Western-Centre-for-Islamic-Finance.pdf [access: 15.10.2017].

Damak M., 2017, Islamic finance outlook, S\&P Global Ratings, New York.

Dudley D., 2016, Islamic banking needs to break out, Euromoney, April 25, 2016.

El Hawary D., Grais W., Iqbal Z., 2004, Regulating Islamic financial institutions: The nature of the regulated, World Bank Policy Research, Working Paper no. 3227, http://documents. world bank.org/curated/en/918931468761945251/pdf/wps3227islamic.pdf [access: 15.10.2017].

EY, 2015, World Islamic banking competitiveness report 2014-15, London, http://www.ey.com/ Publication/vwLUAssets/EY-world-islamic-banking-competitiveness-report-2014-15/ \$FILE/EY-world-islamic-banking-competitiveness-report-2014-15.pdf [access: 15.10.2017].

FAME, [n.d.], database of European listed companies, Bureau van Dijk, https://www. bvdinfo.com/en-gb/our-products/data/national/fame [access: 15.05.2017].

FSB, 2015, Global shadow banking monitoring report 2015, Financial Stability Board, http://www. fsb.org/wp-content/uploads/global-shadow-banking-monitoring-report-2015.pdf [access: 15.10.2017].

Gov.UK, 2014, Government issues first Islamic bond, https://www.gov.uk/government/news/ government-issues-first-islamic-bond [access: 15.10.2017].

HMT, [n.d.], Offering circular, HM Treasury UK Sovereign Sukuk PLC, https://www.sukuk. com/sukuk-new-profile/hm-treasury-uk-sovereign-sukuk-plc-2057/ [access: 15.10.2017].

Islamic Banker, 2017, Sharia Supervisory Board, https://www.islamicbanker.com/education/ shariah-supervisory-board [access: 15.10.2017].

IFSB, 2013, Islamic financial services industry: Stability report, Islamic Financial Services Board, http://www.ifsb.org/docs/IFSB\% 20-\% 20IFSI\% 20Stability\%20Report \%202013\%20 (Final).pdf [access: 15.10.2017].

Iqbal Z., Mirakhor A., 2011, An introduction to Islamic finance: Theory and practice, Wiley \& Sons, Hoboken.

Jenkins P., 2012, HSBC's Islamic closures highlight dilemma, Financial Times, October 7, 2012.

JP Morgan Chase, [n.d.], SEC filings, https://investor.shareholder.com/jpmorganchase/ sec.cfm?view $=$ all [access: 15.01 .2015$]$.

Jessop N., Bell S., 2009, Islamic finance a key to London's future prosperity, Tax Planning International Review: Special Supplement, 01/09, Bloomberg BNA.

Konwicki P., 2015, Will Islamic finance solve the growth problem for 'all mankind'?, Economia, http://economia.icaew.com/opinion/july-2015/will-islamic-finance-solve-the- growthproblem-for-all-mankind [access: 15.10.2017].

ORBIS, [n.d.], database of global listed companies, Bureau van Dijk, https://www.bvdinfo. com/en-apac/our-products/company-information/international-products/orbis [access: 15.05.2017].

PEW, 2015, The future of world religions: Population growth projections, 2010-2050, PEW Research Center, Washington.

UKDMO, [n.d.], Gilt market, United Kingdom Debt Management Office, http:// www.dmo. gov.uk/index.aspx?page $=$ gilts/ about_gilts [access: 15.10.2017]. 
Vizcaino B., 2014, Luxembourg's debut sukuk sees strong demand from government accounts, Reuters, http://www.reuters.com/article/luxembourg-sukük-idUSL6N0RW0DY20141001 [access: 15.10.2017].

WB, 2016, Islamic finance: A catalyst for shared prosperity?, http://www.irti.org/English/News/ Documents/438.pdf [access: 15.10.2017].

The Banker, 2015, Top Islamic financial institutions, special report, The Banker, November 2015.

The Economist, 2014, The market for Islamic financial products is growing fast, 13 September 2014.

P. Konwicki (『) Piotr.Konwicki@uwl.ac.uk

The Claude Littner Business School, University of West London, Boston Manor Road, Brentford, Middlesex TW8 9GA, United Kingdom 


\section{Appendix 1: Structuring issues in Islamic finance: UK sukūk}

The below flowchart presents a typical, very simple structure of a fixed-rate interest bond issued by any non-Muslim sovereign country.

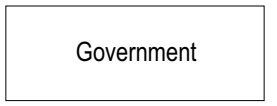

Periodic distributions (coupons) \& final payment at maturity

\section{Purchase price}

Figure 1. Typical bond structure

Source: Own elaboration based on generally available bond presentations.

UK government bonds (gilts) are issued using short-form documentation with no disclosure and few risk factors. In case of failure of payment, the holders of gilts rely upon the Crown Proceedings Act 1947 to secure their recourse against Her Majesty's Treasury, which is responsible for developing and executing the British government's public finance policy and economic policy (UKDMO).

$\mathrm{UK}$ is the first non-Muslim sovereign country which issued sukük. Figure 2 shows the actual structure of this instrument.

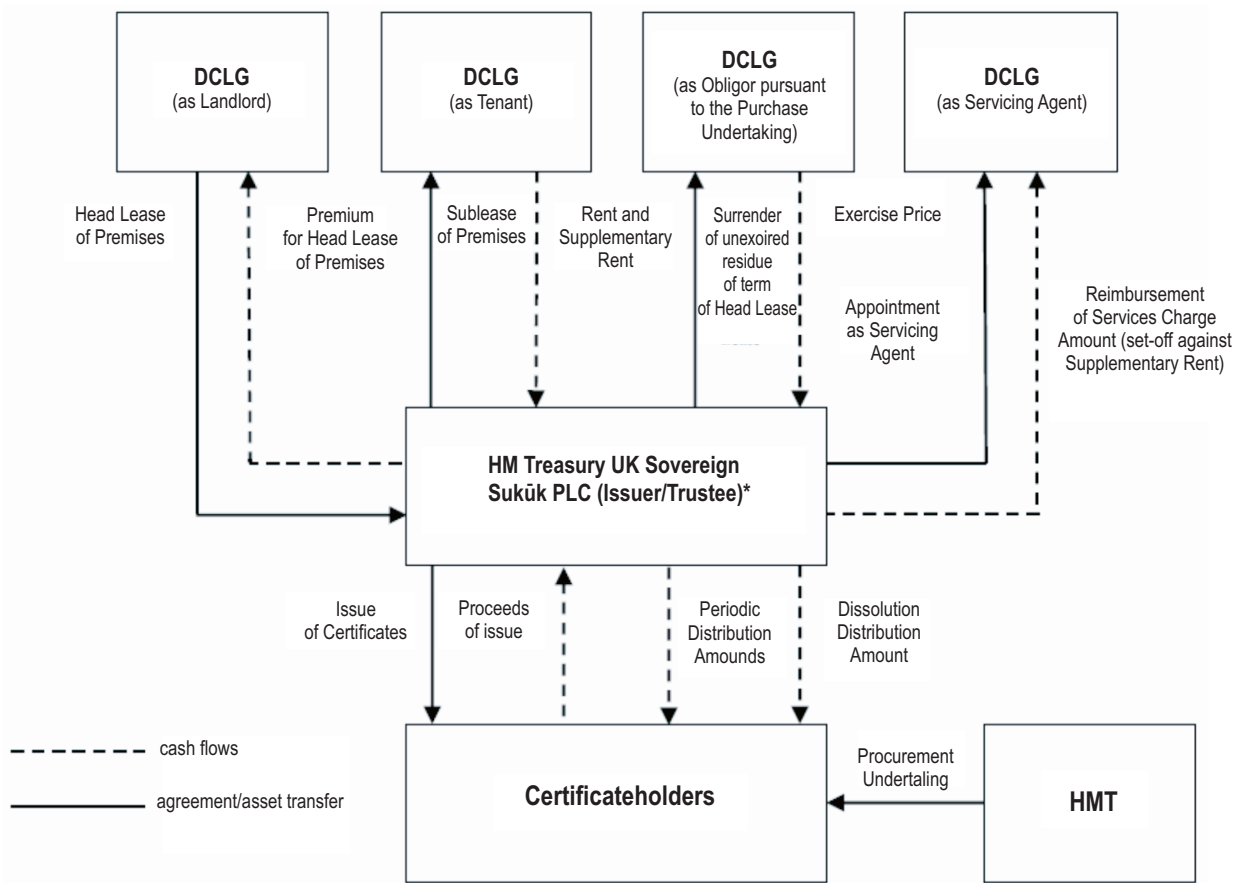

Figure 2. UK sukūk structure

Source: [HMT]. 


\section{Appendix 2: Lack of standardisation: A case study of Islamic mortgage product in the UK}

In 2004, HSBC Amanah, an Islamic window of this global bank, started offering an Islamic mortgage based on Al Ilajara (lease) scheme. To launch this product (which has also been offered in the UK, Malaysia, Bangladesh, Bahrain, and Singapore), HSBC obtained a full approval of this scheme by its own Sharia Board. Figure 1 presents a typical flow of payments and documents within this product.

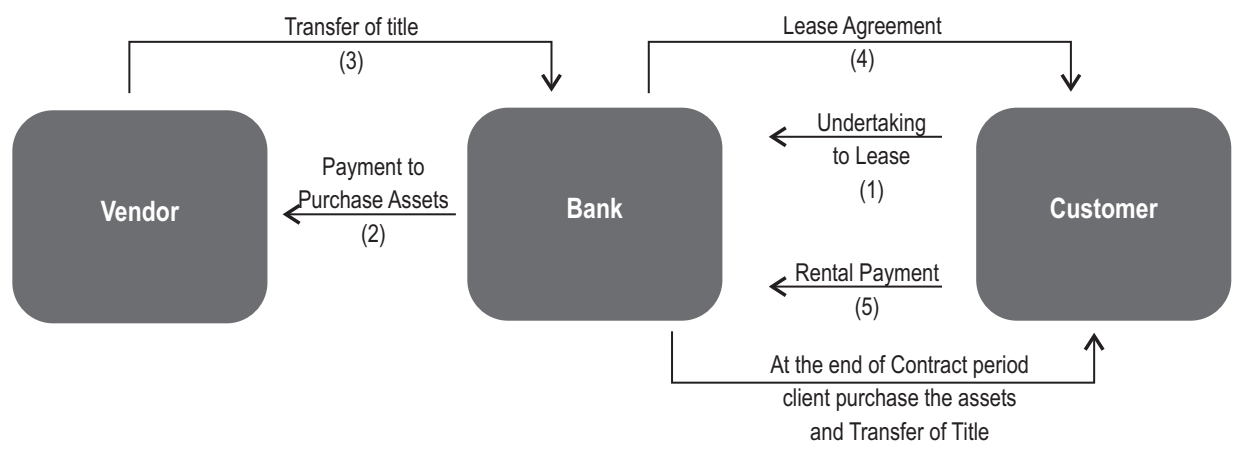

(6)

Figure 1. Al Ijara flow figure

Source: Own elaboration based on generally available literature on Islamic finance.

The product became very controversial and drew the attention of other Islamic scholars. Below there is a full text of Islamic ruling issued by one of the highly respected scholars in the UK. In essence, Shaykh Al-Haddad claims that this product does not meet the requirements of Islamic finance and should be classified as haram, i.e., Muslims should not buy it.

The ruling on the permissibility of financing properties using ijara Islamic mortgages Fatwa by Shaykh Haitham Al-Haddad

Many people have enquired about the permissibility under shari'ah of the socalled Islamic mortgages recently announced by banks such as HSBC. As it is in the interest of all Muslims to have a current and accurate understanding of the issues involved here, I have concluded the following judgment based upon the Qur'an and sunnah in accordance with the understanding of the main school of thoughts.

Let me first brief the reader regarding the manner in which the scheme works.

Under the ijara (rental) variety of Islamic mortgage, the bank purchases a property selected by the client, following a promise from the client that he or she will live in that property and purchase it after an agreed period of time. In return, the 
client pays monthly instalments to the bank, mainly composed of two payments. One portion of the instalment is considered to be a payment of the purchase price for the property, and another portion is counted as rent that the client pays for living in the property in the meantime. The purchase price paid by the client is equal to the purchase price initially paid by the bank for the property. Once the client has paid all of the instalments, in other words the purchase instalments plus the rental instalments, the bank will transfer the ownership of the property to the client. The bank makes its profit from the difference between the price it pays for the property (including related transaction costs) and the amounts received in instalments from its client.

This type of scheme, with some minor modifications, is used in the United Kingdom by HSBC Amanah Finance, Ahli United Bank and United National Bank.

In principle, an ijara scheme can be structured in such a way as to be acceptable under shari'ah so long as certain conditions are met, the discussion of which is beyond the scope of this judgment. However, the implementation of the scheme by the above banks is highly problematic.

Firstly, the contract is ambiguous in terms of its nature. Is it a lease contract, a purchase contract or a combination of the two? Some scholars have prohibited combined contracts (for example, a transaction that combines both lease and purchase), as the Prophet, peace be upon him, prohibited two transactions in one transaction. This is the opinion adopted by most of the scholars, and although there are some who have allowed this type of transaction under certain strict conditions, there is a consensus that the presence of a significant amount of ambiguity invalidates a contract. Among the many Prophetic traditions on this point is that of Ibn 'Umar, who related that the Prophet, upon whom be peace, forbade sales that involve uncertainty or gharr (ambiguity).

Many scholars, including the foremost figh councils of our times believe that if rental and sale are mixed in such a way that one cannot distinguish at any point of time whether the client is a tenant or a buyer, then such a contract is invalid according to Islamic jurisprudence.

When pressed to clarify the nature of the ijara mortgage, staff in Islamic banking departments frequently describe it as a 'lease ending in a purchase'. Yet if this really is the case, then the ijara mortgage should display the features of a lease throughout the entire time-span of the contract (often as much as 25 years) until it concludes with a purchase event. In other words, the bank will rent the house for a period of time with the promise that it will sell to the client at the end of the tenancy. During the tenancy, the bank will be the legal owner of the property. After the tenancy, the client will be the legal owner.

Although many scholars do not allow this type of combined contract, let us for the sake of argument consider it to be valid according to the opinion of those 
scholars who accept it. When we examine the available ijara schemes more closely, we find that the theoretical structure outlined above does not exist in practice. The ijara contract as it stands is neither a lease nor a purchase. Rather, it is closer to a conventional loan where the bank lends money to a client for a property purchase, and requires that the client must repay with a markup (under the guise of 'rent').

Consider the following questions which illustrate the ambiguity of the contract:

1. Why does the tenant need to pay a large down payment? (Frequently an amount equal to $10 \%$ of the price is required. A genuine tenant does of course make some kind of down payment, relevant to the period of the tenancy, but no credible tenancy agreement can bind the tenant to place such a large down payment.)

2. Who pays the insurance of the house? Is it the bank or the tenant? (Technically, the owner of an asset is the one who should pay for its insurance.)

3. What will happen if there is loss or damage to the property and the insurance company refuses to cover the losses incurred? Who will pay for this? (Once again, if the bank is the actual owner, and such a loss or damage occurred through no fault of the client, then the bank cannot hold the client responsible for damages.)

4. If the tenant decides to stop the tenancy agreement, the bank will sell the property. If the price of the property has depreciated in the meantime (which means the bank as the owner of the property suffers a loss), why is the client bound to compensate that entire loss while being only a tenant?

The point of all these questions is to address the central issue, namely, who is considered the actual owner (and thus liable for any damages or depreciation in value) for the duration of the lease? Is it the bank (in which case all of the above scenarios do not make sense), or is it the client (in which case this contract is not a lease contract in the first place, but rather something else)?

A bank may give an answer to all or some of these questions, supported by quotations from jurists past or present. Some of these answers may indeed prove to be acceptable when looked at in isolation but, when taken as a whole, such practices may invalidate the contract.

To illustrate our point, the bank might state that, according to a particular school of thought, the down-payment is not a part of the price of the property since it is not a purchase agreement. Rather, it is an assurance that the tenant is serious in renting the property for a given period of time (up to 25 years, perhaps). Such a condition is acceptable according to some jurists. Furthermore, the bank may state that the insurance is paid by the tenant based on a mutual agreement, and there is nothing wrong with such a condition, for the Prophet, peace be upon him, said: 'Muslims are bound to the conditions taken on by themselves'. 
In the meantime, they might claim that they are bound by English law to hold the title of the property, and will only pass it to the client upon the final payment. However, the contractual agreements that are signed between the bank and its client put all of the risks of ownership upon the client, and these factors defeat the purpose of ijara, even if technically speaking the bank claims to follow the letter of the English law as the 'owner' of the property.

In the above we see arguments that are each, on their own, widely considered to be valid. However, this should not lead us into the grave error of assuming that three valid matters when combined produce a valid outcome. Take, for example, the plain riba transaction, but in the following framework:

1. An interest-free loan, (which is something recommended)

2. A gift, (which is again, something recommended)

3. A promise.

Taken individually, these three transactions are completely valid. However, if they are combined in a single contract, the result is pure riba. For example, I say, 'Grant me a loan which I will repay you (a valid matter), and I promise you (a second valid matter) a gift (a third valid matter) in addition to the repayment when it becomes due'. Is this contact valid or is it riba? The answer is that it is manifest riba without any doubt, since the one who gave the money was promised that same amount back along with some profit.

So, we need to look at the end-to-end process here and evaluate it as one transaction. And we need to answer the critical question: who is the real owner of the property during the whole process? Is it the client while the bank is just financing the deal as it does in a normal conventional mortgage? Or is it the bank? If the owner is the bank, then does a real owner free himself from any responsibility towards his property? Why does the bank avoid owning the property?

Here, we need to explain an enormously incorrect methodology in deriving Islamic verdicts. A verdict should be derived by looking at a matter in its totality, in light of the aims behind it. When we break the matter of discussion into sub-issues and treat issues separately, without looking at the overall picture, then we are contradicting the right methodology in deriving verdicts. The reason is very simple: verdicts based upon sub-issues might not necessarily be the same as verdicts based upon a consideration of the general situation.

A very good example is the previous one. Each sub-contract taken individually is completely valid, but taken as a whole the entire contract becomes null since it is a clear riba transaction. Based on this, many if not all jurists forbade contracts which try to employ such deception.

As another example to further illustrate our point, let us look at the transaction known as 'iynah. This transaction is strictly prohibited by the Prophet, peace be upon him, and its prevalence is a sign that the Muslim ummah will decline. The 
Prophet, peace be upon him, said: 'When you trade with one another with 'iynah, and hold on to the tails of oxen, and are content with farming, and give up jihad, Allah will cause humiliation to prevail over you, and He will not withdraw it from you until you return to (your commitment) to Islam' [Narrated by Ab Dawd. The intent of the hadith is that when Muslims are going to be content with this world, and not care about how they acquire wealth, Allah will inflict upon them humiliations and disgraces that will remain with them until they repent and give up their ways].

This transaction, when broken down into individual parts and examined solely upon these parts, appears to be valid. However, when taken as a whole, it is clearly a type of riba.

How exactly does 'iynah occur? One of the means of practising 'iynah is that one party sells a product to a second party on a deferred payment. The second party then sells it back to the seller at a lesser price, but in cash. If you break this transaction into sub transactions you can conclude that there are two acceptable sale transactions. It is allowed for a person to sell a product for a deferred payment, and it is also allowed to buy a product for cash. However, the ultimate aim of this transaction is to enact a pure riba transaction. This is because the second party receives an amount of cash from the first party and is then required to pay back an amount of greater value at a later time. As for the product itself, since it changes hands twice, it returns to the initial 'seller'. Therefore, the product is used merely as a loop-hole to avoid the prohibition on riba.

This clearly illustrates that we cannot ignore the total aims of any transaction. Jurists mention this rule as a principle that is employed for all business transactions. This principle states:

'The consideration of a transaction is to be paid to its intention rather than its format.' or, alternatively: 'Transactions are judged according to intention.'

Of the evidences for this principle is the hadith of the Prophet: 'Actions are judged according to intentions.'

It is true that some people might say that scholars disagree with this concept, but those scholars who disagree with this concept (like Imam ash-Shafi'i), agree with all other scholars that the aim of the transaction should not be to overcome a prohibited transaction. In other words, all scholars are in agreement that it is sinful for two parties to try to devise a scheme that appears to make permissible something that the Shari'ah declares impermissible.

I therefore conclude that there is no significant difference between the ijara scheme outlined above and the conventional mortgage which is a pure riba-based loan. Under the ijara scheme, the bank performs what is essentially a money lending transaction, placing such conditions upon its clients that guarantee, for all practical purposes, that it will obtain the same amount of money in return plus 
a profit disguised as 'rent'. It might be true that many of the individual clauses and conditions of the contract are permissible (or, at best, subject to a difference of opinion among scholars), but when put together and examined as a whole, it is apparent that there is little that separates this contract from a simple mortgage. Of the many matters that clearly illustrate this is that the risks and rewards of ownership of the house are carried by the tenant, not the bank, regardless of who is the 'paper-owner' under English law.

Allow me to provide a real Islamic scenario for acquiring a house, and also mention a philosophical and ideological approach in explaining a very important principle in Islamic finance. If two or more parties enter a business transaction, then of course their ultimate aim is profit. Islam, being the religion of ultimate justice, does not confer advantage to any party based on one's worldly and materialistic power. In other words, in a permissible Islamic transaction, a powerful, richer person will not have any guaranteed advantage over a powerless, poor person. Both parties have to share the same risk of loss, just as they want to share the joy of profit. This is a very logical and simple - yet powerful - principle, which is an explanation of the Islamic rule: 'There shall be no profit without (a risk) of loss'.

This principle is based on many Prophetic traditions, such as: 'It is not permissible to sell something on condition that the purchaser lends you something. And it is not permissible to have two conditions in one transaction. And no profit is permissible unless possession has been taken of the goods. And you cannot sell what is not in your possession'.

In another hadith, the Prophet, peace be upon him, forbade selling any item from the same place where it was bought; a buyer must first physically acquire these items (lit. 'add them to his own luggage'), then he may sell these goods.

The point of this rule is that whenever an investment contract is structured such that one party is guaranteed a profit, something is simply not right. Only in a pure riba transaction will there be guaranteed profit. Any permissible transaction in the Sharia'h must have an element of risk involved, no matter how small that element is.

Therefore, when looking at this particular transaction, it is essential that the bank (the stronger party) not take advantage of the client (the weaker party) by exploiting the financial power of the former and the desperate need of the latter. If these banks enact their transactions with this principle as an underlying morale framework, I think such contracts that we now see will disappear. Yet, the reality is far from this ideal. In light of this principle, we should always ask the following question: Do these banks share with their clients the risk of loss, or are they are stipulating all possible conditions to protect themselves against any foreseeable loss? Additionally, do these so-called Islamic banks own the properties they are renting to people? 
If we give sincere answers to the questions in discussion, we will see that the current ijara schemes are almost identical to conventional mortgages. They appear to be a ruse designed to promote conventional interest-based practices using Islamic terminologies and Sharia'h expressions.

Based on this, the ijara scheme as it is implemented here in the UK by major banks: Ahli United Bank (formerly called the United Bank of Kuwait), United National Bank and HSBC is totally prohibited. In fact, it is a deception rooted in riba. Until the Muslims in charge of these schemes prove that the above argument is invalid and give clear answers to the questions highlighted earlier, I believe that such transactions are totally prohibited, and I warn brothers and sisters not to get involved with them. I would also like to emphasize that the view of some Muslims, that this scheme is better than the conventional riba-based mortgage alternative and should therefore be used until a pure halal scheme is available, is incorrect. This is because there is no significant difference between the two schemes. And Allah knows best.

written by Haitham Al-Haddad

$1^{\text {st }}$ Dhul-Qa' dah 1425 - December 12, 2004

Final Note:

In 2012, following the review of its global operations, HSBC decided to limit its retail Islamic banking operations to Malaysia and Saudi Arabia, closing Amanah branches in all other countries. At the same time, HSBC decided to continue its Islamic operations, however, they will be mostly a corporate-driven franchise. In 2012, for example, HSBC was the largest corporate sukük arranger [Jenkins, 2012]. 